\title{
FIOS DA TRAMA POÉTICA DE ADRIANO ESPÍNOLA
}

\section{The poetic plot strands of Adriano Espínola}

\author{
Antônio Donizeti Pires \\ UNESP/Araraquara - UnB \\ adpires@fclar.unesp.br
}

Resumo: Este ensaio pretende, na primeira parte, proceder a uma apresentação crítica da obra em progresso do poeta Adriano Espínola, inclusive levando em consideração a discussão atual sobre os caminhos da poesia brasileira contemporânea. $\mathrm{O}$ ensaio completa-se com uma segunda parte analítica de duas formas tradicionais caras ao poeta: o soneto e o haicai.

Palavras-chave: Poesia brasileira contemporânea. Crítica. Adriano Espínola. Soneto. Haicai.

ABSTRACT: This essay intends, in a first part, to undertake a critical presentation of the work in progress of the poet Adriano Espínola, including taking into account the current discussion on the ways of Brazilian contemporary poetry. The text is completed with a second analytical part of two traditional ways guys to the poet: the sonnet and the haiku.

Keywords: Brazilian contemporary poetry. Critical. Adriano Espínola. Sonnet. Haiku.

\section{O poeta, a tradição e a fortuna: apresentação crítica}

Adriano Espínola nasceu em 1952, em Fortaleza, mas vive no Rio de Janeiro. Formado em Letras, é doutor pela UFRJ com tese defendida sobre Gregório de Matos, recentemente publicada: As artes de enganar: uma análise das máscaras poéticas e biográficas de Gregório de Matos (Rio de Janeiro: Topbooks, 2000). Professor universitário, lecionou na UFC, na Université Stendhal Grenoble III (França) e na UFRJ. Como poeta, estreou em 1981 com Fala, favela, longo poema dramático-narrativo, de cunho social, concluído em 
1979 (em homenagem aos moradores da favela José Bastos, de Fortaleza, despejados de seu habitat, em dezembro de 1978, pelo poder público e pela especulação imobiliária). Encenado entre 1980 e 1981, em Fortaleza, Mossoró e João Pessoa, o longo poema mereceu uma segunda edição em 1998 (bilíngue português-francês, Fala, favela / Voilà favela, traduzido por Silvia Rouquier), com a seguinte observação do poeta: "Embora o poema tenha sido escrito em 1979 e publicado dois anos depois, a problemática social - a dos sem-teto e sem-terra -, que motivou a criação do texto, continua infelizmente atual no Brasil." (ESPÍNOLA, 1998, p. 12).

Para além da questão social, que de um modo mais sutil perpassará a produção posterior de Espínola, já se vislumbra neste primeiro livro o universo caótico da cidade moderno-contemporânea, tema fundamental da poesia do cearense (de Fortaleza ao Rio de Janeiro; e destas a algumas cidades europeias e norte-americanas, como Paris e Nova York, mas com ancoragens necessárias em outras emblemáticas metrópoles brasileiras - São Paulo ou Salvador) ${ }^{24}$. Por esta razão é que Domício Proença Filho, na antologia Concerto a quatro vozes (2006), o qualifica de "A voz da urbe".

A produção poética de Espínola prossegue com $O$ lote clandestino (1982; 2. ed. 2002, com substanciais modificações); Trapézio (1984); Táxi (1986) e Metrô (1993) - ambos, revistos em 1996, foram publicados juntos, em segunda edição, no volume Em trânsito (Táxi/Metrô). Após, tem-se Beira-sol (1997), Praia provisória (2006) e a antologia pessoal Escritos ao sol (2015), além do instigante

${ }^{24}$ Segundo Pedro Lyra, em Sincretismo: a poesia da Geração 60, Adriano Espínola publicara em 1976, em Fortaleza (Ed. do A.), sob o pseudônimo de Pedro Gaia, o livro Cidade. Ainda que indisponível nas livrarias, bibliotecas e rede virtual de "sebos" brasileiros, tal primeiro livro (talvez renegado, pois jamais republicado pelo poeta) já no título corrobora seu interesse temático. 
Malindrânia (2009), cujos textos em prosa (de estofo oníricofantástico) o poeta nomeia de "(Relatos)".

A pequena obra de Adriano Espínola (composta, até agora, de nove livros) tem merecido a atenção da crítica brasileira e estrangeira. Um de seus primeiros críticos, Wilson Martins, em Pontos de vista 11 (19 e 26/2/1983), já saúda o poeta de O lote clandestino: "Não destaco esse volume por ser o pior, mas antes por ser um dos melhores na massa dos que se publicam" (MARTINS, 1995, p. 206). A apreciação do crítico continua pelos anos seguintes, acompanhando a produção do poeta: em 14/12/1996 (Pontos de vista 14), comenta Em trânsito (Táxi/Metrô), colocando a poesia de ambos os livros sob a égide expressionista/futurista:

[...] o que nos interessa no momento é estabelecer a genealogia estilística e mental de Adriano Espinola [...], cujo expressionismo, raro em nossa literatura [...], responde ao programa futurista de 1909: 'a poesia deve ser uma sequência ininterrupta de imagens novas' [...]; além disso, é preciso orquestrá-las 'dispondo-as segundo um máximo de desordem'. [...] Adriano Espinola é o último rebento dessa família, menos temporão do que pareceria à primeira vista, não só pelo vigor sugestivo dos seus versos, mas também, em aparente paradoxo, como representante de uma renovação literária ainda mal percebida. (MARTINS, 2002, p. 314; aspas do autor; grifos meus).

Os termos grifados evidenciam que o poeta, ainda vincado por certos "trejeitos marginais" no livro de 1982, amadurece consideravelmente nos dois subsequentes, agora definindo sua posição entre os renovadores da poesia brasileira dos anos 80/90. No texto seguinte, "Famílias de sensibilidade", de 11/10/1997 (Pontos de vista 14), Martins apresenta Beira-sol e assim se reporta ao poeta Adriano Espínola: 
[...] este último entrega-se às virtualidades expressivas dos jogos vocabulares e idiomáticos [...] Adriano Espínola, como se sabe, é o nome exponencial de sua geração, a geração que teve 20 anos na década de 70 e pôde instintivamente superar tanto o artificio neoclássico de 45 quanto os exercícios tipográficos do concretismo e o 'protesto' gratuito que se seguiu em reação previsivel. É o homem para quem a substância da poesia é a língua, mundo de vogais e consoantes, veículo da aventura espiritual em que buscamos, e os poetas encontram, a chave das perguntas irrespondiveis. (MARTINS, 2002, p. 471-472; aspas do autor; grifo meu).

Enfim, Wilson Martins, em 10/2/2001 (O ano literário 20002001), chega a tecer ácidas críticas à tese de doutoramento de Espínola, cujas ideias sobre as máscaras poéticas de Gregório de Matos não endossa e com as quais não concorda em absoluto. Porém, como a tese doutoral de Espínola não está em discussão aqui, avancemos a partir dos anteriores postulados do crítico, cuja avaliação geral é importante porque enfatiza a maneira pela qual Espínola, nutrindo-se de várias tradições, mas ultrapassando-as (talvez não tão "instintivamente", como quer o crítico), vem construindo sua poética bastante pessoal. É o que ressaltam, inclusive, os vários outros críticos brasileiros (Antônio Carlos Secchin, Glauco Ortolano, César Leal, Fernando Py, André Seffrin, Waly Salomão, Antonio Cicero...) e estrangeiros (Charles A. Perrone, Catherine Dumas, Elizabeth Lowe...), cujas apreciações o poeta, conscienciosamente, faz publicar nas "orelhas" e nas contracapas de seus livros (sem contar os prefácios - de um Eduardo Portella, por exemplo - e as "Notas de oficina - I e II", que o poeta inseriu no volume Em trânsito), numa espécie de revivescência do "Poema-orelha" drummondiano, na abertura de $A$ vida passada a limpo (1959): "Esta é a orelha do livro / por onde o poeta escuta / se dele falam mal / ou se o amam. / Uma orelha ou uma boca / sequiosa de palavras? [...]" (ANDRADE, 2015, p. 290). 
No exterior, além da participação em antologias poéticas em Portugal, Espínola tem poemas traduzidos e publicados em vários florilégios da Itália, México e Espanha. Porém, a tradução mais importante de um trabalho seu deu-se em 1992, quando o brasilianista Charles A. Perrone traduziu Táxi e o fez publicar pela Garland Publishing (Londres e Nova York), na prestigiosa coleção World Literature in Translation.

No Brasil, além das duas antologias citadas, Adriano Espínola aparece em várias outras, como Antologia da nova poesia brasileira (1992), de Olga Savary; Pedras de toque da poesia brasileira (1996), de José Lino Grünewald; Outras praias/Other shores: 13 poetas brasileiros emergentes/13 emerging Brazilian poets (1998), de Ricardo Corona; Antologia comentada da poesia brasileira do século 21 (2006), de Manuel da Costa Pinto; Antologia comentada de literatura brasileira: poesia e prosa (2006), de Magaly Trindade Gonçalves, Zélia Thomaz de Aquino e Zina C. Bellodi; Contos cruéis: as narrativas mais violentas da literatura brasileira contemporânea (2006), de Rinaldo de Fernandes; Roteiro da poesia brasileira: anos 80 (2010), de Ricardo Vieira Lima.

Antologias, como se sabe, podem ser muito pessoais, arbitrárias e reducionistas, e às vezes se travestem de meros veículos do mercado livreiro/editorial. Porém, podem funcionar para a divulgação deste ou daquele autor, deste ou daquele grupo, e com isto buscam a demarcação/imposição estética de autores e grupos, ou mesmo das posições pessoais, éticas e estéticas, do próprio antologista. Outra questão, não menos relevante, é que as antologias também servem de termômetro da aceitação/projeção crítica deste ou daquele autor. Com isto, quer-se dizer que a fortuna crítica de Adriano Espínola, em construção, passa necessariamente pelas antologias citadas (além de outras, claro), e tal movimento nos leva a 
questionar alguns procedimentos de divulgação/apreciação da obra em progresso do poeta.

A primeira dessas antologias a chamar a atenção é a de Pedro Lyra (1995), que, através do substantivo qualificador "Sincretismo", pretende estudar e estabelecer as características daqueles poetas (estreados majoritariamente na década de 1960) que a historiografia e a crítica literária, de fato, têm nomeado cada vez mais como poetas da "Geração 60", a exemplo do que fazem os poetas-críticos Álvaro Alves de Faria e Carlos Felipe Moisés em Antologia poética da Geração 60 (2000), esta mais voltada para os poetas que estrearam nos anos 60 num contexto paulistano, conforme alertam os antologistas: “'Geração 60" designa tão-somente poetas surgidos naquele período - em São Paulo, convém frisar." (FARIA; MOISÉS, 2000, p. 11), ao contrário do alcance nacional que a antologia de Lyra procura rastrear. Obviamente, não está em discussão a poesia "sincrética" da "Geração 60", mas o fato de Pedro Lyra inserir Adriano Espínola (nascido em 1952 e com estreia em livro em 1981!) como poeta pertencente a tal geração, por mais que ele explique seus motivos na longa e utilíssima "Introdução" (LYRA, 1995, p. 15-172) com que abre o livro, e por mais que assim considere os três longos poemas de Espínola (Metrô, 1993; Táxi, 1986; "Minha gravata colorida..." - fecho de O lote clandestino, 1982): "Essa trilogia, centrada na vigorosamente sugestiva simbologia da viagem, é a autêntica epopeia brasileira da pós-modernidade" (p. 109). Sim (tende a concordar o poeta e toda a sua fortuna crítica), mas os três são poemas dos anos 80-90, o que por si só nos levaria a qualificar o trabalho de Espínola entre o daqueles poetas (de evidente pluralismo estético) que começaram a publicar nos anos 80 , tal como efetivamente o faz Ricardo Vieira Lima em Roteiro da poesia brasileira: anos 80 (2010), em que procura estudar "os quatro tipos" da "lírica multifacetada", de "saudável polifonia de vozes em que se transformou a poesia brasileira 
contemporânea, sobretudo a partir do início da década de 1980" (LIMA, 2010 , p. 7). Tais quatro linhas, inspiradas em Benedito Nunes ${ }^{25}$, seriam:

${ }^{25} \mathrm{O}$ ensaio de Benedito Nunes em questão é "A recente poesia brasileira: expressão e forma", publicado em 1991 (Novos estudos CEBRAP) e depois recolhido em livro (2009). Entre outras questões fulcrais para a compreensão da poesia brasileira dos anos 80 (o foco do estudo) - e depois -, Nunes ressalta que esta "é pouco ruidosa e nada polêmica" (NUNES, 1991, p. 175), se comparada com a de décadas anteriores; atém-se mais ao livro do que ao suplemento literário dos jornais; sua crítica está enfaticamente ligada à Universidade; apresenta “dicções várias" (p. 178), vários níveis de hibridismo e "pluralismo estético" (p. 178), pois "em nosso tempo, a arte poética não pode ter uma só medida; ela não é mais canônica, é uma composição de cânones" (p. 178), uma vez que foi ultrapassada a "urgente pressão da busca do novo - o império da poesia moderna" ( $p$. 178). Ainda segundo Nunes, a década de 80 - e depois - aparece vincada pelo que chama de "esfolhamento das tradições, inclusive da própria tradição moderna." (p. 178; grifos do autor). Em palavras do filósofo: "Esfolhamento das tradições quer dizer: a conversão de cânones, esvaziados de sua função normativa, em fontes livremente disponíveis com as quais incessantemente dialogam os poetas. Depara-se-nos a convergência, o entrecruzamento dos múltiplos caminhos por eles percorridos, que são outros textos, de tempos e espaços diferentes, na cena literária móvel do presente" (p. 179; grifos meus). [Na edição em livro consta "enfolhamento" (NUNES, 2009, p. 167-168), porém o organizador não esclarece se Nunes preferiu a mudança (mantendo a conceituação acima) ou se foi um lapso (uma gralha) da editora.] Enfim, esboçado o panorama geral, o críticofilósofo sintetiza "certas constantes ou linhas características, que configuram o híbrido perfil poético" (NUNES, 1991, p. 179) da cena contemporânea (p. 179-183), dentre as quais: a "tematização reflexiva da poesia"; a "técnica do fragmento"; o "estilo neoretórico"; a "configuração epigramática"; a "tendência mitogônica"; o "lúdico". Acima, grifei a palavra convergência porque ela é o sustentáculo, também, do poeta-crítico Octavio Paz, em texto datado de agosto de 1986 ("Ruptura e convergência", em A outra $v o z$ ): "Uma vez chamei a poesia deste tempo que começa de arte da convergência. Assim a coloquei do lado oposto à tradição da ruptura. [...] 'A estética da mudança acentuou a natureza histórica do poema; agora nos perguntamos: não há um ponto em que $\mathrm{o}$ princípio da mudança se confunde com o da permanência?... A poesia que começa neste fim de século - não começa realmente nem tampouco volta ao ponto de partida: é um perpétuo recomeço e um contínuo regresso. A poesia que começa agora, sem começar, busca a interseção dos tempos, o ponto de convergência. Diz que entre o passado esmaecido e o futuro desabitado, a poesia é o presente.' Escrevi estas frases faz 15 anos. Hoje acrescentaria: o presente se manifesta na presença e esta é a reconciliação dos três tempos. Poesia da reconciliação: a imaginação encarnada num agora sem datas.” (PAZ, 2001, p. 56-57; aspas do autor.) Penso que as proposições dos dois críticos respectivamente se iluminam (e iluminam toda a discussão posterior, crítico-teórica, sobre 
a) "Lírica de tradição"; b) "Lírica de transgressão"; c) "Lírica vitalista";

d) "Lírica de síntese ou unificadora" (LIMA, 2010, p. 16-18). Se a primeira procura "promover a chamada "tradição renovada" (p. 16) a partir do "diálogo com as fontes clássicas da poesia brasileira e estrangeira (sobretudo as culturas grega, francesa, portuguesa e inglesa)" (p. 16), a segunda busca, através de novos códigos e linguagens, "a chamada "poesia de invenção"” (p. 17), de aposta vanguardista, enquanto a terceira, herdeira da poesia marginal, está calcada "no binômio "arte/vida" (p. 17) e defende "as políticas do corpo e da ideologia" - em suma, a "poesia das tribos" (p. 17; grifos do autor). Enfim, a quarta linha, "Lírica de síntese ou unificadora", segundo Lima, "é a vertente pluralista por excelência" (p. 18) e, "conforme o próprio nome expressa, sintetiza ou unifica as vertentes anteriores, mesclando tradição, ruptura e vitalidade" (p. 18). Evidente que o antologista insere neste quarto tipo o trabalho de Adriano Espínola, numa tentativa clara de compreender os vários caminhos plurais que sua poesia em progresso vem trilhando.

Quatro anos antes, Domício Proença Filho, no prefácio que escreve ("Poesia brasileira contemporânea: multiplicidade e dispersão") para Concerto a quatro vozes, também considera: "A marca da poesia brasileira, desde os anos 70, é a multiplicidade de tendências. Configura-se o que me permito chamar de "Movimento de dispersão"" (PROENÇA FILHO, 2006, p. 7; aspas do autor; grifos meus) ${ }^{26}$. Depois

poesia, notadamente no Brasil), bem como clareiam a nossa compreensão da poesia contemporânea (dos anos 80 a esta parte), em geral, e a compreensão particular do poeta Adriano Espínola, cujo trabalho "enfolha" e "esfolha" tradições variadas, em busca de uma poética convergente, pessoal.

${ }^{26} \mathrm{Na}$ antologia organizada por Ricardo Corona também há referência à "multiplicidade de ideias" e à "diversidade de dicções" (CORONA, 1998, p. 13) na poesia brasileira contemporânea. Outros antologistas, ainda que não enfoquem a poesia de Espínola, também se reportam à "[...] atual pluralidade - 
de percorrer os principais "movimentos" poéticos dos anos 50/60/70, o crítico chega aos 80/90/00 e constata que aqueles "movimentos" se dispersaram "num universo de individualidades." (p. 14). Porém, "no âmbito da dispersão, é possível perceber quatro tendências dominantes, cuja maior ou menor incidência aguarda [reconhece o crítico], para sua configuração, o rigor da pesquisa" (p. 14), uma vez que chega aos milhares, de norte a sul do Brasil, os poetas e as individualidades poéticas em ação, neste começo de século XXI. As quatro tendências seriam, resumidamente: a) "A tradição revitalizada"; b) "A tradição modernista revisitada"; c) "Ecos das vanguardas dos anos 50/70"; d) "A emergência de segmentos preocupados com a afirmação da identidade cultural" (p. 14-16). Não é preciso um exercício agudo de inteligência para aproximar as quatro vertentes arroladas por Vieira Lima das quatro pressupostas por Proença Filho: "Lírica de tradição" é igual a "tradição revitalizada"; "Lírica de transgressão" equivale a "Ecos das vanguardas dos anos 50/70"; assim como "Lírica vitalista" corresponde ao que o segundo considera "A emergência de segmentos preocupados com a afirmação de identidade cultural". Por fim, a pluralista "Lírica de síntese ou unificadora" reflete-se em "A tradição modernista revisitada", se considerarmos que esta também é plural e contém desde a figura dessacralizadora de um Oswald de Andrade, que bem ensinou a seus pósteros a lição antropofágica, até poetas fundamentais como Manuel Bandeira, Carlos Drummond de Andrade, João Cabral de Melo Neto, Murilo Mendes etc. É nesta vertente que Proença Filho situa a poesia de Espínola, avaliando-a do seguinte modo:

de vozes, estilos, linguagens.” (MIGUEL, 2009, p. 9); “[...] a produção poética contemporânea se mostra como uma confluência de linguagens, um emaranhado de formas e temáticas sem estilos ou referências definidas. Nesse conjunto, salta aos olhos uma surpreendente pluralidade de vozes, o primeiro diferencial significativo dessa poesia." (HOLLANDA, 1998, p. 11). 
É o poeta da cidade e sua vertigem, que também empresta sua palavra aos desvalidos. Cultor de uma poesia inquietamente multifacetada, marcadamente original, feita de imagens $e$ ritmos múltiplos, inscreve-se no que me permito chamar a tradição modernista revitalizada. (PROENÇA FILHO, 2006, p. 17).

Aliás, um rápido percurso pela obra altamente intertextual de Adriano Espínola daria a ver, realmente, a demarcação da "família" estética e espiritual a que ele pertence: a primeira edição artesanal de $O$ lote clandestino (1982) abre-se com uma epígrafe de Mário de Andrade (realocada, na edição de 2002, para abertura da segunda seção do novo livro, "Urbs"), enquanto o autor confessa, no explicativo texto final "Dívida externa" (suprimido na edição de 2002), as muitas relações dialógicas e intertextuais que seus poemas estabelecem:

Embora não considere originalidade alguma a utilização de versos alheios na composição do poema - recurso que os criticos mais recentes denominam de intertextualidade - o autor, na falta de maior criatividade, passa aqui a referendar sua divida para com aqueles que lhe emprestaram a ideiaforma, ou a forma-ideia, no todo ou na parte, de alguns dos poemas que compõem este livreto, escrito, como diria Machado, com a caneta da galhofa e a tinta da melancolia (ESPÍNOLA, 1982, p. 65).

Entre os "credores", ressalte-se a presença de poetas modernistas brasileiros, em sua maciça maioria (Bandeira - onipresente -, Drummond, Cassiano Ricardo, João Cabral, Ascenso Ferreira, Vinicius de Moraes, Oswald de Andrade, bem como o poeta popular Patativa do Assaré, o romântico Juvenal Galeno e os desconhecidos poetas - ao menos a este que escreve - Artur Eduardo Benevides e Horácio Dídimo), além de referências ao prosador Machado de Assis e aos compositores Caetano Veloso e John Lennon. Além deste, os outros estrangeiros que comparecem são portugueses (Fernando Pessoa - 
ortônimo e heterônimo - e Sá-Carneiro); franceses (Baudelaire, Mallarmé, André Gide e Sartre); um espanhol (García Lorca); um alemão (Brecht); um russo (Maiakóvski) e uma anglo-americana (Gertrude Stein).

O exercício pode ser estendido a livros posteriores de Espínola, mas frisemos apenas Metrô (aberto com epígrafes de Gregório de Matos, Paul Éluard e Sófocles), também vincado pelo intertexto apologético ou ironicamente desconcertante, porém com um repertório mais alargado de autores, em relação aos trabalhos anteriores do poeta. Claro que neste ainda estão presentes, maciçamente, os modernistas (Bandeira, Joaquim Cardoso, Drummond, Vinicius, Mário de Andrade, Cecília Meireles, Jorge de Lima, Murilo Mendes, Raul Bopp, Ferreira Gullar...), alguns românticos e um parnasiano (José de Alencar - uma das obsessões de Espínola -, Gonçalves Dias, Olavo Bilac...), bem como compositores, cordelistas/repentistas e poetas populares nossos (Chico Buarque, Catulo da Paixão Cearense, Sivuca, Cazuza, Luiz Melodia, Caetano Veloso, Chiquinho do Pandeiro, Azulão...). Todavia, há lugar para os clássicos greco-latinos (Virgílio, Catulo, Homero - em várias ocasiões, e assim desconstruído nos versos "a aurora com seus dedos poluídos / me puxando para mais uma batalha." (ESPÍNOLA, 1996, p. 73), ou nos versos "A aurora com seus dedos rosa-mangueira abre de vez / a Enseada de Botafogo" (p. 142)...); para alguns mitos gregos (Orfeu e Odisseu - o poeta e o viajor exemplares, respectivamente); e também para poetas estrangeiros de tempos e lugares variados (Baudelaire, Rimbaud, Pablo Neruda, Walt Whitman, Ginsberg, Burroughs, Luís de Camões, Dante Alighieri...).

Tal enumeração de autores talvez seja excessiva e gratuita, por um lado, mas por outro faz exacerbar tanto as relações metapoéticas e intertextuais de Espínola com autores da tradição clássica, da tradição modernista (sobretudo) e, claro, da tradição oral-popular do Nordeste 
brasileiro, às quais se juntam, ainda, a relação de nosso poeta com certa cultura massiva, urbana, tanto musical (MPB) quanto pictórica - as pichações das grandes cidades, que têm equivalência, na poesia de Espínola, no modo por que ele vai "pichando", ao longo de poemas como Táxi e Metrô, por exemplo, versos em tipos variados, em itálico e em negrito, como a manchar e a esculpir o branco da página em soluções visuais interessantes (a segunda e a terceira partes da segunda versão de O lote clandestino, "Urbs" e "Grafites", também são exemplares do que aqui se afirma). Enfim, todas essas fontes são de suma importância para o "estilo "nômade"” (PINTO, 2006, p. 191; aspas do autor) de Adriano Espínola, conforme o qualifica o crítico Manuel da Costa Pinto, pois o cearense "se apropria de diferentes formas e dicções poéticas - o que inclui desde o soneto clássico e o poema em prosa até o cordel e a poesia visual" (p. 191), passando pelo haicai e o poema em versos livres e brancos há muito consagrado pelo Modernismo brasileiro e internacional. O risco de tal estilo, segundo Pinto (p. 191), "seria cair no ecletismo, na mera demonstração de virtuosismo técnico", mas o antologista reconhece que sempre "existe uma motivação de fundo para essa poética feita de mutações” (p. 191), uma vez que Espínola, dependendo do livro e/ou do tema a desenvolver, busca explorar uma forma condizente com o assunto (a toada popular e o improviso repentista em Fala, favela, por exemplo; ou o verso longo e espraiado, de estofo épico e caleidoscópicas imagens urbanas, de Táxi e Metrô; ou a exploração do soneto clássico em Beira-rio, de reflexão lírica mais pessoal; ou os poemas densos em versos curtos, de rara concisão construtivo-polissêmica, de Praia provisória). Por outra via (mas complementar), Espínola (poeta essencialmente urbano) "faz da multiplicação de poéticas uma forma de dar conta da pluralidade de experiências que caracteriza a vida na cidade.” (PINTO, 2006, p. 192). Em outros termos, a assertiva crítica ressalta que a multiplicidade de 
tendências que se observa na lírica brasileira contemporânea, como um todo, encontra na poética de Adriano Espínola, de per si, uma corroboração válida das muitas preocupações semânticas e construtivas, éticas e estéticas, que fomentam e fundamentam nossa poesia atual. Assim, frise-se que não seria difícil encontrarmos, nas quatro linhas esboçadas por Proença Filho e por Vieira Lima, uma espécie de interpenetração de todas no trabalho em andamento de Adriano Espínola, claro que sob a égide do que o primeiro considera "A tradição modernista revisitada".

Em outro diapasão, considerando com Costa Pinto que a obra de Espínola é "feita de mutações" (PINTO, 2006, p. 191), penso que tais "mutações" atingem inclusive as várias edições de um mesmo livro, pois este pode apresentar, conforme já apontado, "substanciais modificações" em sua estrutura geral e, igualmente, na estrutura e no significado de cada poema, conforme atestam as duas edições de $O$ lote clandestino: dos 30 poemas da primeira, 9 foram suprimidos na segunda (ora acrescida de 5 novas composições), sendo que vários dos 21 reaproveitados tiveram seus títulos, sua forma e seus versos ligeira ou drasticamente alterados. Por exemplo: "Sapataria” (ESPÍNOLA, 1982, p. 13), em versos livres e brancos, teve o título mantido, mas foi transformado num poema em prosa (ESPÍNOLA, 2002, p. 47); "Velho tema” (ESPÍNOLA, 1982, p. 40) sofreu cortes drásticos em seu amontoado de versos livres e brancos, teve o título alterado para o conhecido e apreciado "Prateleiras" (ESPÍNOLA, 2002, p. 81-82), em dísticos econômicos, mas a epígrafe de Heráclito foi mantida nas duas versões; "Poemário" (ESPÍNOLA, 1982, p. 24), um bom poema em versos na edição original, mas um tanto poluído visual e graficamente, teve o título mantido na nova edição, mas ganhou uma elegância enxuta e exata em sua nova forma de poema em prosa, com a sutil referência a Mário de Andrade e certo tônus metalinguístico: 
Eis as palavras soltas no poemário da cidade: bêbados noturnos, putas fluorescentes, bichas sonoras, pivetes (oh, minha delicada compaixão pelos vocábulos cedo assassinados!) e carros em disparada na madrugada, imprevisiveis, todos, na branca avenida do papel.

(Não éguas ruças no cio, nem lebres saltitantes do invisivel, nem o touro das marés.)

Mas tudo ali acenando/piscando para mim: neon \& pálpebras, sinais \& estrelas, boquetes \& raptos, bundas \& extases, coxas \& línguas - anúncio iluminado - alta fantasia - de sílabas sonhando sentido - pelas esquinas malfaladas da poesia. (ESPÍNOLA, 2002, p. 71; itálico do poeta; grifos meus).

O grifado nos reporta ao poema de 1982, cujo verso original era: "pixotes (oh, minha delicada compaixão pelos vocábulos cedo abandonados!)" (ESPÍNOLA, 1982, p. 24; grifos meus), em que o tônus metalinguístico reverbera a questão social (os menores abandonados e assassinados na grande cidade, a exemplo do exposto no filme Pixote, de Hector Babenco).

Mas as tais "mutações" são requeridas pelo próprio poeta, que em praticamente todas as novas edições de seus livros assina alguma nota informativo-explicativa sobre os percalços por que passaram tais ou quais livros ou poemas. No "Prólogo" de O lote clandestino, o poeta, depois de explicar o surgimento da primeira edição artesanal do livro, em 1982 (que foi, literalmente, lançado do alto de um edifício no centro de Fortaleza, o Hotel Savanah), justifica-se:

Depois de 20 anos, a releitura, o arrependimento ou talvez a experiência o levaram a eliminar ou a reelaborar, na presente edição, algumas passagens da obra, simulacro da vida ou do passado, os quais restam, no entanto, intocáveis. No processo, alguns novos poemas e versos surgiram. [...] 
Duas novas seções de poemas foram aqui adicionadas: 'Urbs' e 'Grafites'. Embora concebidos, quase todos, na mesma época, ficaram de fora da edição original, devido à impossibilidade técnica de reproduzi-los. De feição gráficoespacial, esses ambíguos exercícios de simetria verbal pretendem servir de contraponto à primeira parte do livro.

Com a publicação agora do poema 'Minha gravata colorida', completa-se a trilogia lírico-épica urbana, ao lado de Táxi ou poema de amor passageiro (1986) e Metrô ou viagem até à última estação possível (1993) [...] (ESPÍNOLA, 2002, p. 7).

Com a nova edição conjunta de Táxi e Metrô não é diferente, segundo as palavras do autor: "Em trânsito reúne dois poemas, Táxi e Metrô. O primeiro, publicado em 1986; o segundo, em 1993. // Cortes, acréscimos, reelaborações foram inevitáveis no processo de releitura e preparo da atual edição.” (ESPÍNOLA, 1996, p. 7). Vejam-se também, nesta edição, as "Notas de oficina - I e II" que o poeta pospõe aos poemas, e em que esclarece, a pedido de seu editor, as "circunstâncias superficiais de surgimento" (p. 151) dos dois longos textos, além de enumerar os muitos intertextos que as viagens de táxi e metrô lhe foram suscitando.

Mesmo na antologia pessoal do autor, Escritos ao sol, ele salienta: "No preparo desta antologia, fiz alterações em alguns poemas [...]" (ESPÍNOLA, 2015, p. 137).

A meu ver, todo este conjunto de notas pessoais, explicativas e/ou justificativas, é de suma importância porque dá a ver os andaimes da obra em processo de Adriano Espínola. E, se as diferentes versões de um dado poema causam dificuldade ao analista, penso que o jogo lúdico do poeta deve interessar como manifestação de sua arte poética; de sua autocrítica e metacrítica; de seus lances metapoéticos, intertextuais, intratextuais e mesmo intersemióticos; e, no total, suas muitas notas ultrapassam o mero papel de explicações circunstanciais para 
desvelarem o verdadeiro projeto estético (e ético) de Adriano Espínola, cujas pelejas com a própria poesia (e a alheia) estão sempre em contínuo movimento, numa espécie de mimetização/atualização da aventura quixotesca e/ou da flecha de Iracema, este outro mito sempre desejado por Espínola, e que por certo se corporifica na amada mulher-musa Moema, "esta mulher marinha e moema" (ESPÍNOLA, 1996, p. 69), água primordial de todos os livros do poeta.

No próximo tópico tentar-se-á apreender um pouco mais desse movimento incessante, agora a partir da análise e da interpretação de duas formas fixas privilegiadas pelo cearense: o soneto e o haicai.

\section{O poeta, o soneto e o haicai: apontamento de casos}

Adriano Espínola tem um livro inteiro de haicais, Trapézio (1984), mas nenhum dedicado apenas ao soneto, esta outra forma fixa de sua predileção. Assim, a presente análise centrar-se-á em um haicai extraído do livro Metrô (Em trânsito, 1996) e em alguns outros aparecidos em Trapézio e republicados na antologia de 2015, Escritos ao sol. Quanto aos sonetos, será privilegiado o conjunto de Beira-sol (1997) e também o único soneto de Metrô, sempre em busca dos muitos fios que entramam a poesia do cearense ${ }^{27}$. Antes, porém, algumas palavras sobre ambas as formas fixas.

A palavra soneto, como se sabe, procede de "som" (son, desde o provençal), daí o diminutivo em italiano, sonetto, significando, segundo

${ }^{27}$ Infelizmente, para o momento não será possível a apreciação de Praia provisória (2006), mas ao menos fique registrado que neste livro o poeta preocupou-se, amiúde, com a desconstrução métrica, rítmica e gráfico-visual do soneto tradicional, chegando a explorar, por exemplo, em "Sousândrade", o metro de apenas uma sílaba poética: "yea! / na / lín / gua // por / tu / guesa / a // por / tou / er // rante / um / guesa" (ESPÍNOLA, 2006, p. 63). 
o Dicionário de termos literários de Massaud Moisés, "melodia, canção" (MOISÉS, 1995, p. 480). O soneto, "sol e sal da pura forma", segundo o qualifica José Lino Grünewald (1987, p. 19) em sua antologia dedicada aos melhores da língua portuguesa, é uma forma poética fixa nascida na Idade Média e conceituado pelos dicionários do seguinte modo: "Composição poética de catorze versos, dispostos em dois quartetos e dois tercetos." (MOISÉS, 1995, p. 480). Se houve, durante talvez séculos, forte polêmica sobre as origens provençais ou italianas do soneto, hoje é consensual que a primazia de sua origem e definição de formas e regras se deve aos italianos, conforme nos ensina o Dicionário de Moisés e o alentado O mundo maravilhoso do soneto, de Vasco de Castro Lima (1987) - obra desigual e repetitiva, por certo, sutilmente contrária ao que considera as "extravagâncias do Modernismo", mas densa de informações históricas e conceituais em suas mais de 1000 páginas dedicadas apenas a essa forma fixa que, a partir da Itália, propagou-se por praticamente todas as línguas europeias. No caso da nossa, é sabido que a "medida nova" chegou a Portugal por Sá de Miranda, pela altura de 1527, quando o poeta retorna de longa viagem de estudos à Itália, e logo atravessou o Atlântico em direção à nascente Colônia brasileira.

A paternidade do soneto, de acordo com Moisés, oscilou a princípio entre o siciliano Pier della Vigna (1197-1249) e o provençal Giraud de Borneil (séc. XII), mas hoje em dia "[...] a maioria dos estudiosos inclina-se a considerar Giacomo da Lentino (1180/1190?1246?), poeta siciliano da corte de Frederico II, inventor do soneto" (MOISÉS, 1995, p. 480-481). E informa o estudioso que, dos 19 sonetos compostos em meados do séc. XIII (entre 1220-1250), "os mais antigos que se conhecem" (p. 481), 15 são de Giacomo da Lentino, um de Jacopo Mostacci, um de Pier della Vigna e dois do Abade de Tivoli. Em seguida, aduz Moisés: "Menos assente, porém, [é] o processo 
formal que teria originado o soneto." (p. 481). Este seria o resultado da junção de 2 strambotti $^{28}$ : o primeiro, de oito versos; o segundo, um sexteto. Segundo o autor, a oitava "se fragmentaria em quatro dísticos ou em dois quartetos" (p. 481), enquanto o sexteto "se fracionaria em três dísticos ou em dois tercetos" (p. 481). Como se vê, na tradição italiana (Petrarca, sobretudo) prevalecem as duas quadras e os dois tercetos em versos decassílabos com sistema de rimas ABBA ABBA CDC DCD - esquema formal que, com ligeiras variações, termina por prevalecer também em Portugal e no Brasil. Em outras literaturas, como a inglesa, a forma apresenta ligeira variação, ancorando-se em três quartetos e um dístico final, com sistema de rimas ABAB CDCD EFEF GG. Tanto num caso como no outro, as variações imantadas a partir dos dois esquemas se farão sentir em vários momentos da literatura brasileira, sobretudo no Modernismo e na contemporaneidade, e poetas como Adriano Espínola, Heleno Godoy ou Paulo Henriques Britto (nos passos de um Jorge de Lima, um Murilo Mendes, um Mário Faustino, um Drummond...) continuamente têm oferecido soluções pessoais a essa forma poética à qual os autores voltam obsessivamente, fazendo do soneto, de fato, a mais longeva e a mais importante de todas as formas fixas da poesia lírica.

Segundo Moisés, outras teorias há sobre a origem formal do soneto, mas hoje "parece fora de propósito a teoria segundo a qual o

${ }^{28}$ Sing. strambotto, "estramboto", que o próprio Moisés define como "Das mais velhas formas poéticas italianas, composta em versos decassílabos" (MOISÉS, 1995, p. 205), de extensão variável, mas com preferência pela oitava e pelo sexteto. Em português, tem-se também "estrambote", a "Estrofe por vezes apensa ao soneto." (p. 205), com, no máximo, três versos. Carlos Drummond de Andrade, em Fazendeiro do ar (1954), fez publicar um famoso "Estrambote melancólico", soneto em versos decassílabos brancos (no caso), seguido de um verso apenas (ANDRADE, 2015, p. 279-280). Entre nós, "soneto estrambótico" (como se qualifica o de Drummond) é o soneto seguido de cauda ou rabo. 
soneto derivaria da canção" (p. 482). Ainda de acordo com o estudioso, "O metro mais utilizado no soneto tem sido o decassílabo" (p. 483), com acentos variáveis (Moisés considera o de cesuras na $4^{\mathrm{a}}, 7^{\mathrm{a}}$ e $10^{\mathrm{a}}$ sílabas, mas são muito comuns entre nós, por tradição camoniana, os acentos na $6^{\mathrm{a}}$ e na $10^{\mathrm{a}}$ - o decassílabo heroico - , ou na $4^{\mathrm{a}}$, na $8^{\mathrm{a}}$ e na $10^{\mathrm{a}}$ sílabas - o decassílabo sáfico). Claro que outros tipos de metros (e de variações acentuais) têm sido explorados no soneto em português (de uma a 12 sílabas), mas o decassílabo tem se firmado o metro conatural da língua portuguesa. Enfim, Moisés (p. 484) assevera: "De início exclusivamente amoroso, com o tempo o soneto passou a glosar temas satíricos, humorísticos, épicos, elegíacos, etc., mas os transes sentimentais parecem inerentes à sua própria natureza." No caso de Espínola, ver-se-á que as questões lírico-pessoais são constantes em seus sonetos, mas também a interrogação metapoética e certa recorrência épico-histórica.

Por sua vez, o haicai aparece como a forma poética estrangeira, de origem exótica (no caso, japonesa), que mais bem se aclimatou à poesia brasileira (nossos parnasianos, por exemplo, na esteira de Victor Hugo e Baudelaire, exploraram o pantum da Malásia, mas este praticamente esgotou-se com o virtuosismo técnico dos próprios parnasianos). No caso do haicai, existem já boas antologias e traduções dos mestres e escolas japonesas no Brasil, bem como farta literatura histórico-críticoteórica sobre a penetração da poesia oriental em nosso país desde o final do século XIX, provavelmente via França, mas particularizada no século XX pelas importantes ondas imigratórias japonesas ao Brasil (1908), cujos descendentes ainda mantêm o cultivo do breve poema e a manutenção de clubes de haicais em várias cidades brasileiras.

Em linhas gerais, Massaud Moisés assim localiza e conceitua o haicai: 
Poema japonês caracterizado pela brevidade, compõe-se de três versos, que somam dezessete sílabas, o primeiro e o terceiro com cinco, e o segundo com sete. De remota e incerta origem, considera-se como seu berço a waka, longeva forma poética de trinta e uma sílabas divididas em versos de cincosete-cinco-sete-sete sílabas, que exprimia um estado emotivo e um sentimento em relação à Natureza. [...] E por estruturar-se em versos encadeados, que atingiam de quando em quando a casa dos cem, passou a denominar-se haikai no renga, ou apenas renga, isto é, poemas cômicos de versos em cadeia. Tal moda palaciana, reinante no curso dos séculos VIII a XII da Idade Média, parece a fonte mais próxima do haicai, cujos primeiros espécimes, no arcabouço e conteúdo que se lhe tornaram próprios, datam do século $X V$, época do poeta Sogi. (MOISÉS, 1995, p. 269-270).

Mas é no século XVII, com Matsuo Basho, que “[...] o haicai ganha a definição, a grandeza e a solenidade que o distinguem até hoje" (p. 270). Por causa da brevidade e concisão, Moisés aproxima o haicai do epigrama grego, mas assevera que aquele "deve concentrar em reduzido espaço um pensamento poético e/ou filosófico, geralmente inspirado nas mudanças que o ciclo das estações provoca no Universo" (p. 270).

Por sua vez, o antologista Rodolfo Witzig Guttilla (Boa companhia Haicai, 2009) complementa algumas das informações básicas veiculadas no Dicionário de Moisés, conforme segue:

Poema de origem japonesa, o haicai descende de uma antiquíssima linhagem que remonta ao século VII depois de Cristo: nesse periodo surge o waka (ou 'poema à moda do país de Wa', como os chineses chamavam o Japão), com versos de cinco e sete fonemas - o equivalente a sílabas métricas no Ocidente. A partir de então, a poesia tradicional japonesa adotará esse metro. Os primeiros waka serão reunidos no 'Man 'yôshû' (ou 'antologia de dez mil folhas', em uma das muitas traduções possíveis), a maior e mais antiga coletânea poética do Japão [...] Elaborada entre os séculos VI e VIII, a 
obra é constituída por vinte volumes e reúne cerca de 4500 poemas.

A forma poética predominante no 'Man'yôsh $\hat{u}$ ' [...] é o tanka, composto de 5-7-5-7-7 fonemas. Também chamado misohitomoji, ou 'poema de 31 sílabas', o tanka dividia-se em duas unidades ou estrofes: a primeira formada por 5-7-5 versos e chamada kami no ku ('primeiro verso'), e a segunda, com 7-7 versos, conhecida como shimo no ku ('último verso'). (GUTTILLA, 2009, p. 7; aspas e grifos do autor).

De acordo com o antologista, durante a Era Heian (794-1185), o tanka passa a ser elaborado por duas pessoas, sendo uma encarregada da primeira estrofe (5-7-5), denominada hokku, e a outra da segunda (77), chamada wakiku. Tempos mais tarde, o hokku (haikai, que significa simplesmente poema de dezessete sílabas) torna-se expressão autônoma, sendo que o terceto atingirá seu apogeu no século XVII, com Matsuo Basho (1644-1694) e sua escola, o qual,

[...] filho de samurai e samurai por nascimento, renuncia à sua classe social para, aos 25 anos, tornar-se monge andarilho. Em sua jornada de autoconhecimento, Bashô [sic] eleva o haicai à condição de kadô (ou 'caminho da poesia'), infundindo a visão de mundo zen em sua criação, herança do confucionismo e do budismo de estirpe Mahayana principalmente a crença na interdependência de todas as coisas da natureza, as grandes e as pequenas. (p. 8).

Entre nós, parece ter sido Monteiro Lobato o primeiro a noticiar o haicai através do pequeno jornal $O$ minarete, que editava em Pindamonhangaba, SP (1906), em cujo artigo "A poesia japonesa" apresentou a tradução de seis breves poemas. Contudo, são lembrados como pioneiros Afrânio Peixoto (Trovas populares brasileiras, 1919) - que já define a forma abrasileirada do haicai, ao afirmar: "São tercetos breves, versos de cinco, sete e cinco pés, ao todo dezessete sílabas.” (PEIXOTO apud GUTTILLA, 2009, p. 32) - e 
Wenceslau de Moraes (Relance da alma japonesa, 1926), sendo que o primeiro livro exclusivamente de "haicais brasileiros" é de Waldomiro Siqueira Júnior (Hai-kais, 1933), logo seguido, em 1939, de Roteiro lírico (Haikais), de Jorge Fonseca Júnior. Antes, porém, um modernista da primeira hora, Luís Aranha, inserira dois haicais em seu longo poema "Drogaria de éter e de sombra” (datado de São Paulo, 1921, mas publicado somente em 1984, em Cocktails), segundo Guttilla os “[...] primeiros haicais concebidos por um poeta brasileiro" (GUTTILLA, 2009, p. 13). Guilherme de Almeida, que nos anos 1930/40 tornava o haicai amplamente conhecido, através de artigos veiculados no jornal $O$ Estado de S. Paulo, publica então seus livros de haicais em 1947 (Poesia vária) e 1951 (O anjo de sal), angariando vários admiradores e seguidores (Abel Pereira, Cyro Armando Catta Preta, Waldomiro Siqueira Júnior). Este último, que estreara em 1933, passa a seguir a forma rígida adotada e defendida por Guilherme de Almeida, que engessa o haicai sob certo rigor parnasiano ao dotar a estrutura tradicional do terceto (5-7-5) com rimas externas e internas (uma violência, talvez, já que o haicai original nunca teve rimas), conforme o diagrama: $\mathrm{A} / \mathrm{B}$ B / A (visualizado melhor em dois poemas canônicos do autor, logo abaixo, sempre seguidos de títulos - outra novidade de Guilherme de Almeida):

\section{"Cigarra”}

Diamante. Vidraça. Arisca, áspera asa risca o ar. E brilha. E passa.

(ALMEIDA, 1993, p. 87;

grifos meus). 


\section{"O haicai" \\ Lava, escorre, agita \\ a areia. E enfim, na bateia, \\ fica uma pepita.}

Se o primeiro evidencia a estação do verão, na figura sintética e metafórica da cigarra, que trisca o ar e risca a superfície de vidro (som/ritmo e imagem, densos e condensados, são fundamentais no poemeto de Almeida), o segundo é metapoético, ao definir claramente o haicai a partir de uma meticulosa atividade humana (no caso, o garimpo). São bons poemas, evidentemente, mas décadas depois o poeta paulista é combatido por uma nova geração crítica e sua estética é renegada por uma nova geração de haicaístas, apoiados agora na plena liberdade concedida ao haicai, enquanto forma e conteúdo (um Millôr Fernandes, por exemplo, e depois um Paulo Leminski, uma Alice Ruiz...). Contudo, outros, de permeio com a liberdade total, aproveitarão a segurança da rigidez introduzida por Almeida (um Pedro Xisto, por exemplo, que transitará entre a poesia visual/concretista e o haicai). E outros ainda, passados outros tempos, explorarão a estética de Almeida quase que à risca, mas deixando de lado a titulação tão cara ao paulista: refiro-me, claro, a Adriano Espínola, cujos haicais são muito diferentes dos tercetos de um Paulo Leminski, por exemplo, conforme se verá mais abaixo. Os dois modos de composição (de um lado, um Leminski; de outro, um Espínola), penso eu, parecem delinear os dois caminhos básicos do haicai no Brasil - mas sempre afirmo grosso modo, pois haicaístas há que dispensam a rima fechada de Espínola, mas não a estrutura tradicional em 5-7-5, totalizando então as 17 sílabas poéticas que definem secularmente o haicai. Contudo, se nos reportarmos ao passado nipônico, veremos que as duas "escolas" dicotômicas foram uma realidade corriqueira no Japão imperial: nos 
séculos XVI e XVII, por exemplo, opunham-se duas principais, a "Teimon-ha" ou "escola de Matsunaga Teitoku" (1571-1653), "que buscava a sofisticação da linguagem e a composição elaborada" (GUTTILLA, 2009, p. 8), e a Danrim-fú ou "templo", a qual, sob a batuta de Nishiyama Sôin (1605-1682), era seguida por monges e artistas populares: sua linguagem "enfatizava o coloquialismo e, em alguns casos, as expressões vulgares e o humor rasteiro, repercutindo, em seus poemas, a temática das coisas simples e cotidianas" (p. 8).

Em abono ao afirmado, arrolo como testemunha o Sr. H. Masuda Goga, autor de O haicai no Brasil (1988), tradução de um estudo seu publicado no Japão em 1986, dando notícia da difusão e da produção haicaísta no Brasil, para quem há "três correntes de opinião" (GOGA, 1988, p. 37-40) sobre o haicai brasileiro, a saber: a) "Os defensores do conteúdo", entre os quais se inserem os que consideram a concisão, a condensação e a intuição características intrínsecas ao haicai, além da emoção suscitada pelo Zen-Budismo: para o autor, o fato de associarse tal corrente filósofo-religiosa ao haicai "constitui tendência quase comum a todos os haicaístas brasileiros" (p. 37); b) "Os que atribuem importância à forma", entre os quais Goga situa Guilherme de Almeida, que, desde o artigo "Os meus haikais" (publicado no jornal O Estado de S. Paulo de 28 de fevereiro de 1937), confessa-se "fortemente fascinado pela forma extremamente curta do haiku" (p. 38); c) Os admiradores "da importância do Kigo - palavra ou termo relativo à estação do ano": entre estes, Goga insere o pioneiro Jorge Fonseca Júnior, que, "Sob a influência de Kiyoshi Takahama [...], defende a importância de termos ligados às estações do ano" (p. 40), bem como considera desnecessária a aplicação de rimas fechadas ao haicai e se recusa a dotá-lo de titulação, como o fazia Guilherme de Almeida. Enfim, as três "correntes de opinião" apresentadas se bifurcam em duas, na verdade, pois a primeira e a terceira apontam mais diretamente para 
os conteúdos tradicionais do haicai, enquanto a segunda tenderia a refletir e a explorar os aspectos de construção. Obviamente que novos conteúdos podem se juntar aos tradicionais (como o haicai logo abaixo, de Espínola), assim como novas soluções formais podem ser buscadas, mas desde que se respeite, penso eu, o poemeto centrado em 17 sílabas.

Nestes moldes, consideremos o haicai seguinte de Espínola, extraído de Metrô, cuja transcrição busca respeitar a publicação original: em caixa alta, itálico e negrito, centralizado na página e por isso destacado dos muitos outros versos em tipografia normal que o antecedem ("uma multidão silenciosa / e ansiosa de partir") e imediatamente o seguem ("Quero seguir sozinho nesta amorosa viafêmea, / que se abre e me abraça de passagem, / me duplica e chama, / me carrega e fere, / me atravessa como um relâmpago"):

\section{O METRÔ TROVEJA. A MASSA, APRESSADA, PASSA. SOLIDÃO. PELEJA.}

(ESPÍNOLA, 1996, p. 75).

O sublinhado indica as duplas de rimas externas (A-A, travando os versos redondilhos menores) e de rimas internas (na segunda e na sétima sílaba poética do verso central, $\mathrm{BB}$, de sete sílabas poéticas ou redondilho maior), sempre seguindo o esquema definido, no passado, por Guilherme de Almeida. Em outros termos, tem-se um poemeto bem construído e hermeticamente fechado em si (o poeta? o trem de metrô que finalmente chega e carrega para longe a massa humana?), mas como que boiando na massa de versos livres e geralmente brancos, de rimas ocasionais, que se espalham em estrofes irregulares a explorar o branco da página num movimento de tensão. O tema do poema é atual (a grande cidade cosmopolita; um modo de locomoção moderno e subterrâneo; a pressa e o trabalho estafante - "peleja"; a multidão 
compacta e massificada, mas composta por seres absolutamente sozinhos e impermeáveis uns aos outros, entre os quais parece que apenas o poeta tem consciência de sua solidão). Claramente, há a apreensão de um momento fugidio que passa, mas este está longe da Natureza e dos conteúdos do haicai tradicional, uma vez que a situação, banalizada, se repete cotidianamente (sem o testemunho cíclico das estações) em qualquer grande cidade do mundo. Ademais, soma-se o aspecto subjetivo da voz poética, que na sequência do poemeto, pela lembrança ou pela ação, vai se intrometendo entre as imagens da cidade, o cotidiano das pessoas, as coxas da amada, "segurando a barra da palavra, / que se ergue / no centro do vagão e da fala - meu falo -" (p. 75). Evidente que a leitura proposta é possível porque o haicai explícito acima transborda de sua forma/conteúdo, angariando novos sentidos durante a viagem e contaminando todo o trecho, pois ele, já se disse, se intromete (como o poeta) dentro de um poema maior, que transcorre em velocidade quase vertiginosa. A situação desse primeiro haicai é sui generis (como o soneto que também se encontra no mesmo Metrô, páginas adiante), pois bem diferente da individualidade irredutível dos muitos haicais de Espínola juntados em Trapézio e depois escolhidos a dedo para os seus Escritos ao sol. Destes, escolhi cinco para apresentar ao leitor: formalmente, seguem as mesmas características do transcrito acima, mas as rimas dos próximos haicais vão marcadas a negrito para ressalto do par de externas (A-A) dos versos primeiro e terceiro (quinta sílaba, respectivamente) e do par de internas (BB) do segundo verso, sempre acentuado pelas cesuras e pelas rimas na segunda e na sétima de suas sete sílabas poéticas:

O sol despertado.

Um galo tenta bicá-lo -

o canto rosado.

(ESPÍNOLA, 2015, p. 99). 
Verde mar bravio -

as dunas brancas e nuas

se movem no cio.

(p. 99).

O mar furioso -

cambraias já cobrem as saias

das ondas em gozo.

(p. 100).

Um cavalo verde

de crina de algas se empina

à beira-mar-vede.

(p. 100).

A lua lá no alto-

na vala, ansiando agarrá-la,

a rã dá um salto.

(p. 101).

Em termos de conteúdo, o primeiro haicai tematiza o cíclico nascer do dia, com o protagonismo da ação dividido entre sol e galo, e certa ressonância da imagem homérica da aurora rosada a colorir o canto do galo: com isto, dir-se-ia que duas tradições encontram-se no poema (a grega e a nipônica), atualizadas no tema milenar do nascer do dia ora elaborado por um poeta brasileiro (o qual dialoga, intertextualmente, com o conhecido poema de João Cabral de Melo Neto, "Tecendo a manhã", mas também com poemas de Ferreira Gullar, Anderson Braga Horta, Marcos Siscar...). Nos outros três haicais, mais um tema milenar: o mar e sua força germinativa e sua beleza algo violenta, sendo que a ressonância do romance Iracema, de Alencar, é evidente no segundo, enquanto se recorre à mitologia grega (os cavalos do deus marinho Netuno) no quarto poemeto. Por seu turno, o quinto (um noturno) dialoga nitidamente com o conhecido haicai de Matsuo Basho 
(traduzido amiúde no Brasil), o qual é colocado, na antologia de Paulo Franchetti et al., na seção "Primavera": "O velho tanque - / Uma rã mergulha, / Barulho de água." (BASHO apud FRANCHETTI el al., 1996, p. 89).

Em suma, a pequena e preciosa forma poética, bem travejada sob o estro de Espínola, procura dar conta de aspectos da tradição e da própria contemporaneidade do poeta, tematizando a Natureza e a cidade, o tempo e o espaço, o dia e a noite, o eu e o outro: realidades cuja passagem/travessia cambiante, pelo sujeito poético, sempre se dá sob o signo da surpresa e da impermanência.

Em relação ao soneto, conforme já explanei, não há um livro de Espínola com poemas que explorem apenas a forma fixa soneto, seja esta da tradição ítalo-luso-brasileira ( 2 quartetos e 2 tercetos), seja da tradição inglesa (3 quartetos e um dístico final). Porém, na primeira parte de Beira-sol, "Claridade", composta de 20 poemas, oito são sonetos, e pode-se dizer que os oito se desdobram em dois núcleos que se articulam em profundidade, conforme segue: o primeiro grupo, mais lírico-reflexivo, compõe-se de três sonetos de tipo inglês ("Línguamar", "O jangadeiro" e "A rendeira"), são metapoéticos e elaboram uma espécie de profissão de fé do poeta no trabalho (do jangadeiro, da rendeira, do poeta), sempre à luz do sol e sob o impacto do mar. A natureza solar e marinha, pois, tem um peso e uma presença fecundante nos três poemas. A natureza também está presente nos outros cinco sonetos, mas de um modo talvez mais virgem e primitivo, um tanto impeditivo (pois precisa ser vencida pelo Homem, a Natureza, embora isto nem sempre seja possível): assim, os outros cinco sonetos ("Vicente Yáñez Pinzón", "Martim Soares Moreno", "Matias Beck", "Matias Beck (2)" e "Silva Paulet") compõem uma espécie de núcleo épicohistórico na primeira parte do livro Beira-sol, "Claridade", e, estruturados de forma inusitada (4 tercetos e um dístico final), voltam- 
se para o passado e cantam personagens históricas que estão ligadas à colonização e à memória do estado do Ceará, em particular, ou à História de grande parte do Nordeste brasileiro (a invasão holandesa).

Começando pelo núcleo épico-histórico (e lendário), frise-se que tem-se aqui mais uma maneira de Adriano Espínola dialogar com o épico (das origens e formativo, no caso), talvez menos evidente em seu trabalho do que o chamado "épico pós-moderno" que o próprio poeta e a crítica insistem em ver nos três longos poemas citadinos Táxi, Metrô e "Minha gravata colorida". Como não será possível transcrever e comentar todos os cinco sonetos desse núcleo (privilegiarei apenas os dois dedicados a Matias Beck), passemos uma vista d'olhos, ao menos, pelas figuras que ostentam: o primeiro (em versos decassílabos ER 610 e sistema de rimas ABB AAB BAB ABA CC) é dedicado ao navegador espanhol Pinzón (1462-1514) - capitão da caravela La Niña e co-descobridor da América (1492) com Cristóvão Colombo -, que esteve no Norte do Brasil (precisamente em Mucuripe, CE, conforme o poema) em janeiro de 1500 (três meses antes da chegada de Cabral em Porto Seguro). Cito o dístico final do soneto, que se fecha numa espécie de chave de ouro lírico-reflexiva: "Navegante do ocaso, em sua jornada, / todo homem busca um mar, um nome, nada." (ESPÍNOLA, 1997, p. 18). O segundo soneto da série é dedicado a Martim Soares Moreno (1586-1648?), importante soldado português (depois elevado a capitãomor) que muito fez pela Coroa na Colônia: é tido como fundador do estado do Ceará e foi imortalizado nas páginas do romance Iracema (1865), de José de Alencar, que não por acaso o subintitulou "Lenda do Ceará". No poema (em versos decassílabos ER 6-10 e sistema de rimas ABB AAB BAC DCD EE), depois que "[...] fundou um forte de colunas / destemidas. [E] Sonhou na areia ardente // uma cidade lusa, clara e rente.” (ESPÍNOLA, 1997, p. 20), retornou às plagas cearenses “[...] num sonho de Alencar / a viver a verdade de uma lenda.” (p. 20). Enfim, 
por efeito de mais um intertexto fabuloso, volta no poema de Espínola, cujo eu-lírico confessa: "Em meu sangue, que é praia do passado, / Martim Soares combate, ressonhado.” (p. 20).

O próximo soneto (o quinto, do núcleo épico) é dedicado a António José da Silva Paulet (1778-1837), engenheiro militar português de ascendência francesa que viveu largo tempo em Fortaleza, e cujos projetos urbanísticos (além do traçado do Forte de Nossa Senhora de Assunção, por exemplo) ajudaram a urbanizar e remodelar a capital cearense nos começos do século XIX: "Aqui fundaste as retas, sim, e o mito / da humana morada do infinito." (ESPÍNOLA, 1997, p. 29), apregoa o dístico final do soneto (em versos decassílabos ER 6-10 e rimas $\mathrm{ABB} A \mathrm{AB} B \mathrm{BAC} \mathrm{DCD} \mathrm{EE})$.

Os sonetos terceiro e quarto (do núcleo épico) são dedicados a Matias Beck (16??-1668), militar, protestante reformado e administrador holandês ligado à Companhia das Índias Ocidentais, o qual chegou ao Brasil em 1636 com a invasão de Maurício de Nassau. Enviado ao Ceará em 1649, no mesmo ano constrói o sólido forte Schoonenborch (junto ao ribeiro Marajaitiba), praticamente no mesmo local em que Martim Soares Moreno fundara a primeira fortaleza da província em 1612. Teve cargos administrativos na Colônia invadida e chefiou uma larga expedição de procura de metais preciosos (prata), parece que não muito bem-sucedida. Deixou o Ceará em 1654 (com a expulsão dos holandeses) e partiu para Curaçao, onde foi governador e onde faleceu em 1668. No imaginário histórico e lendário, Matias Beck disputa com Martim Soares Moreno a fundação da cidade de Fortaleza e, segundo a acesa polêmica ainda em curso no Ceará, foi de fato o fundador da cidade (cujas primeiras ruas foram se trançando em torno de seu forte), enquanto o Moreno é o fundador do estado cearense. $\mathrm{O}$ terceiro soneto, pois, expõe os ideais do invasor, de certo modo mantenedor da ordem e da terra conquistada, mas inebriado pela lenda 
do Eldorado (que perdeu tantas mentes no período colonial latinoamericano) e que ao mesmo tempo pretende fazer da nova terra uma imensa, poderosa (pela espada e pelo comércio), florida e ensolarada Nova Holanda (conforme os versos grifados):

\section{"Matias Beck"}

Tudo em completo estado de defesa, me disse Maes ao ver a obra pronta. Sobre o Marajaitiba, eis que desponta,

de madeira entrançada, a fortaleza. Ao seu sopé, um riacho com certeza abrandará a sede, que já conta,

por este quente areal, que nos afronta. Vamos buscar a prata, adiante, presa no ventre pedregoso da montanha,

que se ergue como chama no horizonte.

Plantaremos tulipas nesta estranha terra de dura luz e frouxo monte.

Com o brilho da prata e da espada, faremos outra Holanda, ensolarada. (ESPÍNOLA, 2001, p. 22; grifos meus).

O soneto em versos decassílabos (ER 6-10) e sistema de rimas $\mathrm{ABB} A \mathrm{AB}$ BAC DCD (nos tercetos) e EE (no dístico) é cristalino em seu tema e significado geral, depois de estabelecido o intertexto histórico. De metro e cesura bem marcados, como todos os outros da série, apresenta uma imagem ritmada que conjuga a natureza exuberante (o sol, a luminosidade) e de incessante movimento (as dunas de areia, o vento) do novo espaço: "Terra de dura luz e frouxo monte." 
Quanto ao quarto soneto da série, "Matias Beck (2)", dir-se-ia o resultado frustrado da empreitada invasora, pois, segundo se sabe, os holandeses foram expulsos do Brasil em 1654, ano da partida de Beck para as Antilhas Holandesas:

“Matias Beck (2)”

Abri picadas, sonhos e veredas, caçando o mineral, que se escondia nos grotões das montanhas e do dia,

no veio dos instantes e das gredas.

Debaixo deste sol em labaredas, na febre de viver, que não cedia,

lutei contra os tapuias com ousadia, cercado de traiçoeiras alamedas. Só encontrei as minas dos enganos:

onde sonhei Holanda, só vi dunas; onde busquei a prata, lavrei danos; no lugar de tulipas, só bordunas.

Sim, deixo a fortaleza e o que mais seja.

Que tudo nesta terra é vã peleja.

O soneto (talvez o mais belo entre os cinco que compõem o que chamei núcleo épico-histórico) também apresenta (como todos os anteriores) alinhamento à esquerda da página e estrofação diferente em relação à matriz do soneto, pois estrutura-se em quatro tercetos (rimados em ABB AAB BAC DCD) e um dístico final (EE), em versos decassílabos (ER 6-10), como é praxe nos sonetos do livro em apreço. Neste, Espínola costuma ousar mais no estrato ótico-gráfico-visual do soneto, e menos em sua estrutura métrica, rítmica e de cesura. Por 
exemplo: o segundo soneto dedicado ao holandês (logo acima) chama a atenção porque já aparecera na segunda edição conjunta de Táxi/Metrô - Em trânsito (ESPÍNOLA, 1996, p. 93), mas com a disposição tradicional de 2 quartetos e 2 tercetos, que portanto condicionam o esquema de rimas externas em ABBA ABBA CDC DEE. E mais: o mesmo soneto reaparecerá em Escritos ao sol (ESPÍNOLA, 2015, p. 68), porém agora com alinhamento centralizado na página; com o novo título "Matias Beck (1654)"; e com disposição estrutural diferente das anteriores, pois o autor, sempre mutante, investirá em uma nova exploração do estrato gráfico-ótico do poema, transformando-o num soneto à inglesa, ao menos visualmente: uma estrofe única de 14 versos, que portanto também condiciona o esquema das rimas finais em ABBAABBACDCDEE ${ }^{29}$.

Tal como acontece com o haicai inserido em Metrô (comentado páginas atrás), a inserção do soneto a Matias Beck aparece num momento em que o

${ }^{29}$ Cumpre salientar que, dos cinco sonetos que compõem o por mim chamado núcleo épico-histórico da primeira parte ("Claridade") de Beira-sol (1997), três serão reproduzidos na antologia de 2015 (Escritos ao sol), mas os três com alinhamento centralizado na página, seguindo a disposição gráfico-visual do soneto à inglesa e com alguma alteração nos títulos respectivos: "Martim Soares Moreno (1612)" (ESPÍNOLA, 2015, p. 66); "Matias Beck (1654)" (p. 68); "Silva Paulet (1812)" (p. 70). Alguma variante ou alteração verifica-se também na construção/sintaxe/léxico dos versos, o que demonstra mais uma vez, para o estudioso, a "ânsia de mutações" que persegue cada nova edição dos poemas de Adriano Espínola. Com o segundo soneto a Matias Beck não é diferente, pois há ligeiras alterações nas três publicações do poema: por exemplo, o quarto verso da primeira estrofe (1996) está no plural, "nos veios dos instantes e das gredas", mas foi passado para o singular nas duas edições posteriores (1997 e 2015): "no veio dos instantes e das gredas"; por seu turno, no terceiro verso da segunda estrofe (1996) consta "lutei contra os Tapuias com ousadia", sendo que em 1997 o gentílico perde a maiúscula inicial ("tapuias") e é substituído por "nativos" em 2015. Evidente que há mais exemplos no mesmo soneto, mas tais variantes (singelamente apontadas aqui) deverão, no futuro, ser objeto de uma edição crítica rigorosa da obra em progresso de Adriano Espínola. 
vertiginoso trem de metrô em que viaja o poeta se transforma num "Metrô-robô 747, da KLM, a 930km/h, / até desabar de repente na Estação Schiphol, em Amsterdam.” (ESPÍNOLA, 1996, p. 92). Isto é, do Rio de Janeiro passamos às terras de Holanda, e doravante (antes e depois da inserção do soneto), o poeta fará citações/alusões/ironias em relação a dados da cultura holandesa e brasileira, condensando tudo num também vertiginoso espaço-tempo:

$[\ldots]$

- num vagão da Nederlandse Spoorwegen, ao lado de Ana de Amsterdam,

que logo me pergunta com açúcar pelos desafetos

de Calabuarque

\& Matias Beck,

perdido

em 1654 por entre as dunas do Ceará:

[...]

Enquanto os doze noturnos de Cecília continuam lá fora a se derramar

por entre os canais da cidade e da memória, com aquela espiritualidade toda flou/vial.

Não, não é o caso, minha senhora, pastora de nuvens.

[...]

Eu, guerreiro tapuia, vou destrinchando o tempo e o corpo do outro, [...]

E agora descubro ser a orelha de Van Gogh, a parte martirizada

[...]

(ESPÍNOLA, 1996, p. 93-95; grifos do autor). 
Em suma, penso que o fragmento é exemplar do processo dialógico e intertextual da poesia de Espínola (conforme frisado páginas atrás), além de estabelecer uma espécie de intratexto das fontes e variantes de sua própria obra.

Em relação aos três sonetos do núcleo lírico-reflexivo da primeira parte de Beira-sol, "Claridade", transcrevo-os abaixo para algum comentário e análise ${ }^{30}$ :

\section{“Língua-mar"}

A lingua em que navego, marinheiro, na proa das vogais e consoantes, é a que me chega em ondas incessantes à praia deste poema aventureiro. É a língua portuguesa, a que primeiro transpôs o abismo e as dores velejantes, no mistério das águas mais distantes, e que agora me banha por inteiro. Lingua de sol, espuma e maresia, que a nau dos sonhadores-navegantes atravessa a caminho dos instantes, cruzando o Bojador de cada dia. Ó língua-mar, viajando em todos nós. No teu sal, singra errante a minha voz.

(ESPÍNOLA, 2001, p. 13).

\section{“O jangadeiro"}

Jangadas amarelas, azuis, brancas, logo invadem o verde mar bravio,

${ }^{30}$ Os três foram reproduzidos na antologia Escritos ao sol (2015) praticamente do mesmo modo como aparecem em 1997, salvo pelo fato de estarem alinhados no centro da página, e não à esquerda. Constatam-se também algumas pouquíssimas variantes (as reticências, por exemplo, foram suprimidas de "A rendeira"), mas nada que altere o sentido profundo de cada um dos três sonetos. 
o mesmo que Iracema, em arrepio, sentiu banhar de sonho as suas ancas.

Que importa a lenda, ao longe, na história, se elas cruzam, ligeiras, nesse instante, o horizonte esticado da memória, tornando o que se vê mito incessante? As velas vão e voltam, incontidas, sobre as ondas (do tempo). O jangadeiro repete antigos gestos de outras vidas feitas de sal e sonho verdadeiro. Qual Ulisses, buscando, repentino, a sua ilha, o seu rosto e o seu destino. (p. 31).

\section{"A rendeira"}

Na teia da manhã que se desvela, a rendeira compõe seu labirinto, movendo sem saber e por instinto a rede dos instantes numa tela. Ponto a ponto, paciente, tenta ela traçar no branco linho mais distinto a trama de um desenho tão sucinto como a jornada humana se revela. Em frente, o mar desfia a eternidade noutra tela de espuma e esquecimento, enquanto, entrelaçado, o pensamento costura sobre o sonho a realidade. Em que perdida tela mais extrema foi tecida a rendeira e este poema?...

Os três poemas passam por sonetos de tipo inglês: estão alinhados à esquerda da página, apresentam-se em uma única estrofe de 14 versos decassílabos (ER 6-10, no costume de Espínola) e têm seu ritmo adensado por marcantes rimas externas em $\mathrm{ABBAABBACBBCDD}$ (o primeiro); ABBACDCDEFEFGG (o segundo); ABBAABBACDDCEE (o terceiro) - 
note-se que o sistema de rimas difere para cada um, mas os três se estruturam, claramente, sob a forma de três quartetos e um dístico final. $\mathrm{O}$ trio compõe uma espécie de unidade metapoética, conforme já referido, a partir da comparação/valorização da atividade do poeta assimilada com (e similar a) outras atividades humanas corriqueiras e eternas (o trabalho da rendeira, do jangadeiro, do navegador...), porque protótipos míticos de atividades inaugurais dos seres humanos, em qualquer civilização, havendo, portanto, uma espécie de chancela do passado em relação ao presente e ao futuro - este aspecto é claríssimo sobretudo no segundo poema, em que o jangadeiro (o poeta-jangadeiro), que "repete antigos gestos de outras vidas / feitas de sal e sonho verdadeiro", é um novo Ulisses a buscar, "repentino, / a sua ilha, o seu rosto e o seu destino." E ao mito grego soma-se o mito da origem brasileira, Iracema (sempre tão presente na poesia de Espínola). A tal ancestralidade e historicidade do trabalho (do poeta e de qualquer ser humano), junta-se a historicidade e a ancestralidade da própria língua portuguesa ("língua-mar" quase infinita), difundida pelo mundo todo a partir das Grandes Navegações e do processo colonizador de Portugal. E, no mote ora glosado por Espínola, ressoa (além de um Vieira e um Fernando Pessoa) um outro mar humano de escritores e poetas que, além de escreverem em português, também pensaram a própria língua portuguesa: assim, o poetajangadeiro-rendeiro acrescenta mais um fio na tessitura de intertexto e metatexto que irmana/imanta todos os seres humanos e que define com mais clareza o espaço da cultura e do trabalho. Neste sentido, pode-se dizer que ressoa uma sutil nota épica na lírica reflexiva e mais pessoal dos três sonetos.

Obviamente que a trabalheira humana tem seus percalços e suas dificuldades, daí todos terem que cruzar "o Bojador de cada dia" em busca de algum desejo ou ideal sempre alhures. Contudo, essa trabalheira se realiza sob as bênçãos de uma exuberante natureza solar e marítima, aparentemente eterna, inviolável e imutável (o mar em que se banhou Iracema e através do qual navegou Ulisses é o mesmo mar 
em frente ao qual a rendeira tece seu labirinto e que, metaforizado em língua, inunda por inteiro o poeta). Sabe-se, claro, que a própria natureza é também mudança e se transforma o tempo todo, mas ela semelha estar-sempre-aí, como que a enfatizar para cada ser humano a brevidade de sua própria vida e de suas canseiras, cuja transcendência parece ser atingida apenas nas imagens ritmadas do poema e na tela da rendeira: "a trama de um desenho tão sucinto / como a jornada humana se revela." Este soneto (a meu ver, uma das mais belas composições de toda a poesia brasileira contemporânea), além de homenagear uma das profissões femininas mais antigas do mundo, a rendeira (o mito da Tecelã de Destinos é perene e inclui Aracne, Penélope, as Moiras ou Parcas, as Valquírias...), e, com isso, dialogar com a MPB e a cultura popular nordestina, também alude, metapoeticamente, ao trabalho inspirado ("por instinto") e artesanal/racional ("Ponto a ponto, paciente") da rendeira e do próprio poeta, que traçam "no branco linho mais distinto" seus labirintos de pontos e palavras. O poema (cuja estrofe única, visualmente, já é uma tela) vai assim sendo tecido tela sobre tela, teia sobre teia, labirinto sobre labirinto (o trabalho da rendeira em si; a outra tela que é o mar em frente, feito "de espuma e esquecimento"; a teia/labirinto da jornada humana sobre a terra; a teia do sonho e a tela da realidade, que se retroalimentam; a tela do dia que prossegue seu curso; a teia/tela do tempo...), numa espécie de espiral infinita que pretende tocar, talvez, o próprio mistério da Divindade: "Em que perdida tela mais extrema / foi tecida a rendeira e este poema?..." - pergunta-se enfim o eu-lírico, ecoando o mundo das Ideias de Platão. Haveria, realmente, um modelo, um protótipo Ideal de cada coisa sensível que há no mundo? Haveria, realmente, um mundo outro onde a Alma, depois de tantas e cansativas jornadas, enfim se aquieta, na contemplação efetiva da Beleza e da Verdade? Haveria Deus, realmente, em pura Ideia? São perguntas demais, está se vendo - e todas 
sem respostas, como sempre o souberam os poetas de todas as épocas e quadrantes (e quase alguns filósofos).

\section{Referências}

ALMEIDA, G. de. Os melhores poemas. Seleção de Carlos Vogt. São Paulo: Global, 1993.

ANDRADE, C. D. de. Nova reunião: 23 livros de poesia. São Paulo: Companhia das Letras, 2015.

CORONA, R. (Org.). Outras praias/Other shores: 13 poetas brasileiros emergentes/13 emerging Brazilian poets. Ed. bilíngue. São Paulo: Iluminuras, 1998.

ESPÍNOLA, A. Escritos ao sol: antologia. Rio de Janeiro: Record, 2015.

. Malindrânia (Relatos). Rio de Janeiro: Topbooks, 2009.

. Praia provisória. Rio de Janeiro: Topbooks, 2006.

. O lote clandestino. 2.ed. Rio de Janeiro: Topbooks, 2002.

. Beira-sol. 5.ed. Rio de Janeiro: Topbooks, 2001.

. Fala, favela. Voilà favela. Tradução de Silvia Rouquier. 2. ed. bilíngue. Rio de Janeiro: Topbooks, 1998.

. Em trânsito (Táxi/Metrô). 2. ed. Rio de Janeiro: Topbooks, 1996.

. O lote clandestino. Fortaleza: Água, 1982.

FARIA, Á. A. de; MOISÉS, C. F. (Orgs.). Antologia poética da Geração 60. São Paulo: Nankin, 2000.

FERNANDES, R. de. (Org.). Contos cruéis: as narrativas mais violentas da literatura brasileira contemporânea. São Paulo: Geração, 2006. 
FRANCHETTI, P. et al. (Org.). Haikai: antologia e história. 3. ed. Campinas, SP: UNICAMP, 1996.

GOGA, H. M. O haicai no Brasil. São Paulo: Oriento, 1988.

GONÇALVES, M. T.; AQUINO; Z. T. de; BELLODI, Z. C. (Orgs.). Antologia comentada de literatura brasileira. Petrópolis, RJ: Vozes, 2006.

GRÜNEWALD, J. L. (Sel. e org.). Pedras de toque da poesia brasileira. Rio de Janeiro: Nova Fronteira, 1996.

. (Sel. e org.). Grandes sonetos da nossa língua. Rio de Janeiro: Nova Fronteira, 1987.

GUTTILLA, R. W. (Org.). Boa companhia Haicai. São Paulo: Companhia das Letras, 2009.

HOLLANDA, H. B. de. (Org.). Esses poetas: uma antologia dos anos 90. Rio de Janeiro: Aeroplano, 1998.

LIMA, R. V. de. (Sel. e prefácio). Roteiro da poesia brasileira: anos 80 . São Paulo: Global, 2010.

LIMA, V. de C. O mundo maravilhoso do soneto. Rio de Janeiro: Freitas Bastos, 1987.

LYRA, P. (Org.). Sincretismo: a poesia da Geração 60 - introdução e antologia. Assessoria Verônica de Aragão. Fortaleza: Fundação Cultural; Rio de Janeiro: Fundação RioArte/Topbooks, 1995.

MARTINS, W. O ano literário 2000-2001. Rio de Janeiro: Topbooks; Curitiba: Imprensa Oficial do Estado do Paraná, 2005.

. Pontos de vista (crítica literária). São Paulo: T. A. Queiroz, 2002 (vol. $14-1995 / 1996 / 1997)$.

. Pontos de vista (crítica literária). São Paulo: T. A. Queiroz, 1995 (vol. $11-1982 / 1983 / 1984 / 1985)$.

MIGUEL, A. (Org.). Traçados diversos: uma antologia de poesia contemporânea. São Paulo: Scipione, 2009. 
MOISÉS, M. Dicionário de termos literários. 7. ed. São Paulo: Cultrix, 1995.

NUNES, B. A recente poesia brasileira: expressão e forma. In: . A clave do poético. Organização de Victor Sales Pinheiro. São Paulo: Companhia das Letras, 2009. p. 158-173.

. A recente poesia brasileira: expressão e forma. Novos estudos CEBRAP, São Paulo, n.31, p. 171-183, outubro de 1991.

PAZ, O. A outra voz. Tradução de Wladir Dupont. São Paulo: Siciliano, 2001. PINTO, M. da C. (Org.). Antologia comentada da poesia brasileira do século 21. São Paulo: Publifolha, 2006.

PROENÇA FILHO, D. (Org.). Concerto a quatro vozes: Adriano Espínola. Antonio Cicero. Marco Lucchesi. Salgado Maranhão. Rio de Janeiro: Record, 2006.

SAVARY, O. (Org.). Antologia da nova poesia brasileira. Rio de Janeiro: Hipocampo/Fundação RioArte, 1992. 